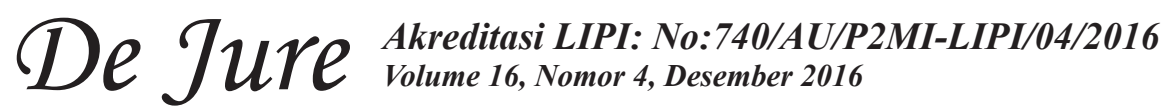

Jurnal Penelitian Hukum De Jure adalah majalah hukum triwulan (Maret, Juni, September dan Desember) diterbitkan oleh Badan Penelitian dan Pengembangan Hukum dan HAM Kementerian Hukum dan HAM RI bekerjasama dengan IKATAN PENELITI HUKUM INDONESIA (IPHI) Pengesahan Badan Hukum Perkumpulan Keputusan Menteri Hukum dan Hak Asasi Manusia Nomor : AHU-13.AHA.01.07 Tahun 2013, Tanggal 28 Januari 2013, bertujuan sebagai wadah dan media komunikasi, serta sarana untuk mempublikasikan aneka permasalahan hukum yang aktual dan terkini bagi para peneliti hukum Indonesia khususnya dan kalangan masyarakat pemerhati hukum pada umumnya.

Penanggung Jawab

Y. Ambeg Paramarta, S.H.,M.Si

(Kepala Badan Penelitian dan Pengembangan Hukum dan Hak Asasi Manusia)

\section{Pemimpin Umum}

Marulak Pardede, S.H.,M.H.,APU

(Ketua Ikatan Peneliti Hukum Indonesia)

\section{Wakil Pemimpin Umum}

T. Daniel L. Tobing, S.H

(Kepala Pusat Pengembangan Data dan Informasi Peneliti Hukum dan Hak Asasi Manusia)

DR. Agus Anwar, S.H.,M.H

(Kepala Pusat Penelitian dan Pengembangan Hukum)

Pemimpin Redaksi

Akhyar Ari Gayo, S.H.,M.H.,APU (Hukum Islam, BALITBANGKUMHAM)

\section{Anggota DewanRedaksi}

DR. Ahmad Ubbe, S.H.,M.H., APU (Hukum Adat, BALITBANGKUMHAM)

Mosgan Situmorang, S.H.,M.H (Hukum Perdata, BALITBANGKUMHAM)

Syprianus Aristieus, S.H.,M.H (Hukum Perusahaan, BALITBANGKUMHAM)

Nevey Varida Ariani, S.H.,M.H (Hukum Pidana, BALITBANGKUMHAM)

Eko Noer Kristiyanto, S.H (Hukum Perdata, BALITBANGKUMHAM)

Muhaimin, S.H (Hukum Islam, BALITBANGKUMHAM)

\section{Redaksi Pelaksana}

Yatun, S.Sos

Sekretaris

M. Virsyah Jayadilaga, S.Si.,M.P

Asmadi

\section{Tata Usaha}

Dra. Evi Djuniarti, M.H

Galuh Hadiningrum, S.H

Suwartono 


\section{TUTe $\begin{aligned} & \text { Akreditasi LIPI: No:740/AU/P2MI-LIPI/04/2016 } \\ & \text { Volume 16, Nomor 4, Desember } 2016\end{aligned}$}

Teknologi Informasi dan Desain Layout

Risma Sari, S.Kom., M.Si (Teknologi Informasi)

Machyudhie, S.T (Teknologi Infornasi)

Saefullah, S.ST.,M.Si (Teknplogi Informasi)

Agus Priyatna, S.Kom (Desain Layout)

Teddy Suryotejo

\section{Mitra Bestari}

Prof. DR. Rianto Adi, M.A (Sosilogi Hukum, UNIKA ATMAJAYA JAKARTA)

Prof. DR. Jeane Neltje Saly, S.H.,M.H (Hukum Humaniter, UNIV. 17 Agustus 1945 Jakarta)

Prof. DR. Hibnu Nugroho, S.H (Hukum Fidana, FH. UNSOED)

DR. Farhana, S.H.,M.H (Hukum Pidana, Fak. Hukum Universitas Islam Jakarta)

DR. Ridwan Nurdin, M.A (Hukum Syariah, Fakultas Syariah Univ. Arraniri Banda Aceh)

DR. Hadi Supratikta (Administrasi Pemerintahan, Balitbang Kemendagri)

\section{Alamat Redaksi:}

Gedung Badan Penelitian dan Pengembangan Hukum dan Hak Asasi Manusia

Kementerian Hukum dan Hak Asasi Manusia Republik Indonesia

Jl. HR. Rasuna Said Kav.4-5, Kuningan, Jakarta Selatan

Telepon, (021)2525015, Faksimili (021) 2526438

Email :

jurnaldejure@yahoo.com

balitbangkumham@gmail.com

ejournaldejure@gmail.com

\section{Percetakan}

PT Pohon Cahaya

Jalan Gedung Baru 18 Jakarta Barat 11440

Telpon (021) 5600111, Faksimili (021) 5670340

Redaksi menerima naskah karya asli yang aktual dalam bidang hukum berupa hasil penelitian dari berbagai kalangan, seperti: peneliti hukum, praktisi dan teoritisi, serta berbagai kalangan lainnya. Tulisan-tulisan yang dimuat merupakan pendapat pribadi penulisnya, bukan pendapat redaksi.

Redaksi berhak menolak, menyingkat naskah tulisan sepanjang tidak mengubah isinya. Naskah tulisan dapat dikirim ke alamat redaksi, maksimum 30 halaman A4, diketik spasi dua rangkap dikirim melalui Email: jurnaldejure@yahoo.com atau melalui aplikasi Open Journal System (OJS) pada URL/website: ejournalbalitbangham.go.id 




\section{DAFTAR ISI}

\section{DAFTAR ISI}

ADVERTORIAL

Implementasi Undang-Undang Nomor 32 Tahun 2014 Tentang Kelautan

(Studi Kasus Prinsip Pencemar Membayar)

(Implementation of The Law Number 32, Year 2014 Concerning Marine)

$451-462$

Muhar Junef

DAFTAR RIWAYAT HIDUP

505 - 506

PEDOMAN PENULISAN

507- 508 


\section{De TuPe $\begin{aligned} & \text { Akreditasi LIPI: No:740/AU/P2MI-LIPI/04/2016 } \\ & \text { Volume 16, Nomor 4, Desember } 2016\end{aligned}$}

Puji syukur kehadirat Allah SWT, Jurnal Penelitian Hukum De Jure yang diterbitkan Badan Penelitian dan Pengembangan Hukum dan HAM Kementerian Hukum dan Hak Asasi Manusia bekerjasama dengan Ikatan Peneliti Hukum Indonesia dapat menerbitkan Volume 16 Nomor 4, Desember 2016.

Para pembaca Jurnal Penelitian Hukum De Jure yang tercinta, sebagaimana diketahui bahwa pada tanggal 10 Desember setiap tahunnya diperingati sebagai Hari Hak Asasi Manusia sedunia. Tanggal ini dipilih untuk menghormat Majelis Umum PBB yang mengadopsi dan memproklamirkan Deklarasi Universal Hak Asasi Manusia, sebuah pernyataan global tentang hak asasi manusia pada 10 Desember 1948.

Apabila menilik Hukum dan HAM, merupakan konsepsi kemanusiaan dan relasi sosial yang dilahirkan dari sejarah peradaban manusia di seluruh penjuru dunia. Hukum dan HAM juga dapat dimaknai sebagai hasil perjuangan manusia untuk mempertahankan dan mencapai harkat kemanusiaannya. Agar HAM dapat ditegakkan dalam berbagai kehidupan harus ada instrumen yang mengaturnya. Instrumen tersebut berisi aturanaturan bagaimana HAM itu ditegakkan dan mengikat seluruh warganegara. Sebagai negara yang menjunjung tinggi HAM Indonesia telah memiliki setidak-tidaknya empat instrumen HAM, yakni UUD 1945, TAP MPR Nomor XVII/MPR/1998, UU Nomor 39 Tahun 1999 tentang Hak Asasi Manusia.

Dari beberapa intrumen yang ada tersebut berharap perlindungan dan penegakan HAM kedepanya dapat meningkat, karena masih banyak kekurangan-kekurangan yang harus diperbaiki oleh pemerintah. Seperti lebih difungsikan secara maksimal lembaga-lembaga yang memiliki tugas khusus menegakan HAM.

Dalam rangka memperingati Hari Hak Asasi Manusia Sedunia tersebut, Dewan Redaksi mengangkat tuisan-tulisan dari para peneliti di lingkungan Kementerian Hukum dan HAM yang bersinggungan dengan penegakan Hukum dan HAM di Indonesia.

Akhirnya kami menyampaikan ucapan terima kasih kepada Kepala Badan Penelitian dan Pengembangan Hukum dan HAM Kementerian Hukum dan HAM RI dan Ketua Ikatan Peneliti Hukum Indonesia dalam penerbitan buku ini. Dan juga kami ucapkan terima kasih kepada Prof. DR. Rianto Adi, M.A., Prof. DR. Jeane Neltje Saly, S.H.,M.H., Prof. DR. Hibnu Nugroho, S.H., DR. Farhana, S.H., M.H., DR. Ridwan Nurdin, M.A.,dan DR. Hadi Supratikta, Selaku Mitra Bestari yang telah bersedia membantu memeriksa dan mengoreksi tulisan dari para penulils.

Jakarta, Desember 2016 


\title{
IMPLEMENTASI UNDANG-UNDANG NOMOR 32 TAHUN 2014 TENTANG KELAUTAN (STUDI KASUS PRINSIP PENCEMAR MEMBAYAR) \\ (Implementation of The Law Number 32, Year 2014 Concerning Marine (Case Study: Principle of one who pollute must be fined)
}

\author{
Muhar Junef \\ Peneliti pada Pusat Penelitian dan Pengembangan Hukum, Badan Penelitian \\ dan Pengembangan Hukum dan Hak Asasi Manusia \\ KementerianHukumdanHakAsasiManusiaRepublik Indonesia \\ Jalan HR Rasuna Said Kavling 4 -5, Jakarta Selatan 12920 \\ Telepon (021)2525015 Faksimili (021)2526438 \\ HP.0813 11649214 - Email: muharjunef@yahoo.co.id \\ Tulisan Diterima: 1-09-2016; Direvisi: 28-11-2016; \\ Disetujui diterbitkan: 23-12-2016
}

\begin{abstract}
Principle of one who pollute must be fined is a principle that often said in international declaration then come into international conventions and become principle of international environment law. This research tries to examine how the practice of who pollute must be fined principle refer to theory; and what approach used Indonesia in its implementation. The result of this research finds that its practices in the Law Number 32, Year 2014 concerning Marine, ruled not in specific terms. But, It still can be implemented if pollution occurred and/ or destruction at sea. Method of this research is normative juridical, intended to explain the Act.
\end{abstract}

Keywords: Principle of one who pollute must be fined

\begin{abstract}
ABSTRAK
Prinsip pencemar membayar adalah prinsip yang sering diucapkan dalam deklarasi internasional yang kemudian masuk ke dalam konvensi-konvensi internasional dan menjadi prinsip hukum lingkungan internasional. Permasalah dalam penelitian ini adalah melihat bagaimana penerapan prinsip pencemar membayar menurut teori; dan pendekatan apa yang digunakan oleh Indonesia dalam implementasi prinsip pencemar membayar. Hasil penelitian ini menemukan bahwa penerapan prinsip pencemar membayar dalam Undang-Undang No. 32 Tahun 2014 tentang Kelautan, tidak secara khusus diatur. Hal tersebut tidak mengakibatkan prinsip tersebut tidak dapat diterapkan bila terjadi pencemaran dan/atau perusakan di laut. Metode yang digunakan dalam penelitian ini adalah menggunakan penelitian yuridis normatif, maksudnya untuk menjelaskan UndangUndang Nomor 32 Tahun 2014 tentang Kelautan yang berkiatan dengan prinsip pencemar membayar.
\end{abstract}

Kata Kunci: Prinsip Pencemar Membayar

\section{PENDAHULUAN}

Setelah 69 (enam puluh sembilan) tahun merdeka, Indonesia akhirnya memiliki UndangUndangNomor 32 Tahun 2014 Tentang Kelautan (Undang-Undang Kelautan $=$ UUK). UndangUndang Kelautan (UUK) ini merupakan produk hukum pertama yang dihasilkan Dewan Perwakilan Rakyat Republik Indonesia bersama Pemerintah dan Dewan Perwakilan Daerah Republik Indonesia. Hal ini dinilai sebagai langkah maju bangsa Indonesia sekaligus menandai dimulainya kebangkitan Indonesia sebagai bangsa bahari.
Alasan dibentuknya Undang-Undang Kelautan (UUK) ini adalah bahwa sumber daya alam Negara Kesatuan Republik Indonesia sebagai negara kepulauan memiliki sumber daya alam yang melimpah yang merupakan rahmat dan karunia Tuhan Yang Maha Esa bagi seluruh bangsa dan negara Indonesia yang harus dikelola secara berkelanjutan untuk memajukan kesejahteraan umum sebagaimana diamanatkan dalam UndangUndang Dasar Negara Republik Indonesia Tahun 1945. Wilayah laut sebagai bagian terbesar dari wilayah Indonesia yang memiliki posisi dan 
nilai strategis dari berbagai aspek kehidupan yang mencakup politik, ekonomi, sosial budaya, pertahanan, dan keamanan merupakan modal dasar pembangunan nasional. Oleh karena itu pengelolaan sumber daya kelautan dilakukan melalui sebuah kerangka hukum untuk memberikan kepastian hukum dan manfaat bagi seluruh masyarakat sebagai negara kepulauan yang berciri nusantara;

Setidaknya ada tiga hal yang melatarbelakangi mengapa Undang-Undang Kelautan (UUK) ini perludisahkan.Pertama, penambahan luas perairan Indonesia ternyata bahwa wilayah laut harus dikelola, dijaga, dan diamankan bagi kepentingan bangsa Indonesia. Kedua,pembangunan sektor laut dinilai masih menghadapi banyak kendala dalam pelaksanaannya, makaperludibuat UUK untukitu. Ketiga, oleh karenanya diperlukan pengaturan mengenai kelautan yang bertujuan untuk menegaskan Indonesia sebagai negara kepulauan berciri nusantara dan maritim sehingga memberikan kepastian hukum dan manfaat bagi seluruh masyarakat Indonesia (http://www. uruqulnadhif.com/2015/06/uu-kelautan-uupengelolaan-wilayah.html, diaksesharisenin, 28 November 2016, pukul 7.30 WIB)

Undang-Undang Kelautan (UUK) ini diharapkan, sebagai pengaturan mengenai Kelautan yang bertujuan menegaskan Indonesia sebagai negara kepulauan berciri nusantara dan maritime yang dalam mendayagunakan Sumber Daya Kelautan dan/atau kegiatan di wilayah Laut sesuai dengan ketentuan peraturan perundangundangan dan hukum laut internasional demi tercapainya kemakmuran bangsa dan negara.Hal itu untuk mewujudkan Laut yang lestari serta aman sebagai ruang hidup dan ruang juang bangsa Indonesia; memanfaatkan Sumber Daya Kelautan secara berkelanjutan untuk sebesar-besarnya kesejahteraan bagi generasi sekarang tanpa mengorbankan kepentingan generasi mendatang; memajukan budaya dan pengetahuan Kelautan bagi masyarakat.

Dengan disahkannya UUK ini, sehingga dalam praktiknya sesuai dengan harapan pembentukannya, hal ini untuk mengatasi permasalahan di bidang kelautan. Dimana pemerintah maupun masyarakat dapat mengatasi permasalahan yang berkaitan dengan pengatutan di bidang kelautan dewasa ini masing-masing terpencar-pencar di berbagai undang-undang yang terpisah, sendiri-sendiri (parsial) dan bersifat sektoral juga berpotensi untuk tumpang tindih, tidak konsisten dan membingungkan dalam pelaksanaannya; koordinasi lintas sektor yang belum efektif dan kurangnya sarana dan alat-alat untuk keperluan penegakan hukum dan kedaulatan di laut. Disamping itu sektor kelautan sangat terkait dengan sektor-sektor lainnya, seperti ekonomi, politik, sosial budaya, dan pertahanan keamanan, sehingga diperlukan usaha untuk mewujudkan keterpaduan pelaksanaan di bidang kelautan melalui metode perencanaan terpusat dan pelaksanaan terdesentralisasi.

Oleh karena itu dalam mengembangkan sumber daya manusia di bidang Kelautan yang profesional, beretika, berdedikasi, dan mampu mengedepankan kepentingan nasional dalam mendukung Pembangunan Kelautan secara optimal dan terpadu; memberikan kepastian hukum dan manfaat bagi seluruh masyarakat sebagai negara kepulauan. Selanjutnya diharapkan dalam mengembangkan peran Negara Kesatuan Republik Indonesia dalam percaturan Kelautan global sesuai dengan hukum laut internasional untuk kepentingan bangsa dan negara.

Penyelenggaraan Kelautan juga dilaksanakan berdasarkan asas keberlanjutan, konsistensi, keterpaduan, kepastian hukum, kemitraan, pemerataan, peran serta masyarakat, keterbukaan, desentralisasi, akuntabilitas, dan keadilan. Lingkup pengaturan dalam penyelenggaraan Kelautan meliputi wilayah Laut.

Pembangunan Kelautan, Pengelolaan Kelautan, pengembangan Kelautan, pengelolaan ruang Laut dan pelindungan lingkungan Laut, pertahanan, keamanan, penegakan hukum, keselamatan di Laut, tata kelola dan kelembagaan, serta peran serta masyarakat.

Di samping itu Indonesia juga dikenal sebagai negara kepulauan terbesar di dunia dengan potensi dan kekayaan alam yang berlimpah sebagai karunia Tuhan Yang Maha Esa memiliki makna yang sangat penting bagi bangsa Indonesia sebagai ruang hidup (lebenstraum) dan ruang serta media pemersatu yang menghubungkan pulau-pulau dalam satu kesatuan ideologi, politik, ekonomi, sosial, budaya, pertahanan, dan keamanan dalam suatu wadah ruang wilayah Negara Kesatuan Republik Indonesia. Kemudian dikatakan bahwa dua pertiga dari wilayah Indonesia merupakan Laut dan merupakan salah satu negara yang memiliki 


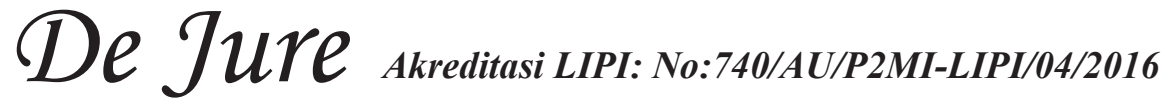

garis pantai terpanjang di dunia. Secara geografis Indonesia terletak diantara dua benua, yaitu Benua Asia dan Benua Australia dan dua Samudera, yaitu Samudera Hindia dan Samudera Pasifik yang merupakan kawasan paling dinamis dalam percaturan, baik secara ekonomis maupun politik. Letak geografis yang strategis tersebut menjadikan Indonesia memiliki keunggulan serta sekaligus ketergantungan yang tinggi terhadap bidang Kelautan.Di samping keunggulan yang bersifat komparatif berdasarkan letak geografis, potensi sumber daya alam di wilayah Laut mengandung sumber daya hayati ataupun nonhayati yang sangat bermanfaat bagi kelangsungan hidup masyarakat. Potensi tersebut dapat diperoleh dari dasar Laut dan tanah di bawahnya, kolom air dan permukaan Laut, termasuk wilayah pesisir dan pulaupulau kecil, sangat logis jika ekonomi Kelautan dijadikan tumpuan bagi pembangunan ekonomi nasional. Oleh karena itu, Laut Indonesia harus dikelola, dijaga, dimanfaatkan, dan dilestarikan oleh masyarakat Indonesia sesuai dengan yang diamanatkan dalam Pasal 33 Undang Undang Dasar Negara Republik Indonesia Tahun 1945 (Penjelasan Undang-Undang Nomor 32 Tahun 2014 tentang Kelautan)

Pembangunan Kelautan dan Kemaritiman merupakan salah satu agenda prioritasdidalam pembangunan nasional tahun 2015-2019. Indonesia sebagai negara kepulauan yang telah diakui oleh dunia sesuai kesepakatan UNCLOS 1982 (United Nations Convention Law Of The Sea 1982), perlu memanfaatkan keunggulan posisi geografis dan geostrategis yang didukung oleh keberagamansumberdaya alam laut yang berlimpah.Segala sesuatu yang berkaitan dengan posisi dankekayaan yang terkandung didalamnya harus dikelola sebagai modal yang strategis untukmewujudkan Indonesia sebagai negara kepulauan yang berorientasi maritim.Amanat pembangunan nasional di bidang kelautan telah digariskan dalam Undang-Undang Nomor 17 Tahun 20017 tentang Rencana Pembangunan Jangka Panjang 2005-2025.Lebihlanjut dalam RPJMN (Rencana Pembangunan Jangka Mengah Nasional) Tahun 2010-2014 telah dirumuskan program lintas bidang pembangunankelautan berwawasan kepulauan yang dilaksanakan oleh $\mathrm{K} / \mathrm{L}$ (Kementerian/Lembaga) terkait. Namun demikian,pengelolaan sumberdaya kelautan tidak cukup hanya mengembangkan modal sumberdaya perikanan, pengelolaan pulau-pulau kecil dan pengamanan wilayah Negara kepulauan Indonesia saja. Masih banyak aspek di bidang kelautan yang perlu dikembangkan dan diwujudkan sebagai modal pembangunan dan pemanfaatkannyauntuk kesejahteraan masyarakat (BAPPENAS, 2014: 1).

Untuk dapat mengidentifikasi isu-isu yang perlu dikembangkan agar modal sumber daya kelautan dapat didayagunakan secara lebih strategis.Permasalah hukum dalamprinsip pencemar membayar yang diatur dalam Pasal 52 Undang-Undang Nomor 32 Tahun 2014 tentang Kelautan yang telah disahkan dan diundangkan di Jakarta, pada Tanggal 17 Oktober 2014 dan Lembaran Negara Republik Indonesia Tahun 2014 Nomor 294. Dalam Pasal 52 Undangundang Nomor 32 Tahun 2014 tentang Kelautan menyebutkan bahwa: (1) Pencemaran Laut meliputi: a.pencemaran yang berasal dari daratan; b. pencemaran yang berasal dari kegiatan di Laut; dan c. pencemaran yang berasal dari kegiatan dari udara. (2) Pencemaran Laut sebagaimana dimaksud pada ayat (1) dapat terjadi: a. di wilayah perairan atau wilayah yurisdiksi; $b$. dari luar wilayah perairan atau dari luar wilayahyurisdiksi; atau c. dari dalam wilayah perairan atau wilayah yurisdiksike luar wilayah yurisdiksi Indonesia. (3) Proses penyelesaian sengketa dan penerapan sanksi Pencemaran Laut sebagaimana dimaksud pada ayat (1) dan ayat (2) dilaksanakan berdasarkan prinsip pencemar membayar dan prinsip kehatihatian. (4) Ketentuan lebih lanjut mengenai proses penyelesaian dan sanksi terhadap Pencemaran Laut dilaksanakan sesuai dengan ketentuan peraturan perundang-undangan.

Adapun menjadi persoalan adalah bagaimana pengaturan prinsip pencemar membayar dalam Undang-Undang Nomor 32 Tahun 2014 Tentang Kelautan ?Bagaimana penerapan prinsip pencemar membayar menurut Undang-UndangNomor 32 Tahun 2014 Tentang Kelautan dan apa hambatan dalam penerapannya dan bagaimana upaya pemerintah dalam mengatasinya?

\section{METODE PENELITIAN}

Metode penelitian yang digunakan dalam penelitian ini adalah menggunakan penelitian yuridis normatif (Soekamto dan Sri Mamuji 1990:15) maksudnya untuk menjelaskan UndangUndangNomor 32 Tahun 2014 tentang Kelautan 
yang berkiatan dengan prinsip pencemar membayar.

\section{PEMBAHASAN}

\section{A. Prinsip Pencemar Membayar Menurut Teori}

Prinsip pencemar membayar adalah prinsip yang sering diucapkan dalam deklarasi internasional yang kemudian masuk ke dalam konvensi-konvensi internasional dan menjadi prinsip hukum lingkungan internasional(Louka, 2006:51.).

Instrumen internasional pertama yang mengacu pada pernyataan prinsip pencemar membayar secara tegas adalah Organitation for Economic Co-operation and Devlopment (OECD) 1872, yaitu sebuah organisasi ekonomi internasional yang didirikan oleh 34 negara pada tahun 1961, yang bertujuan untuk menstimulasi perkembangan ekonomi dan perdagangan dunia. Badan ini mendukung prinsip pencemar membayar untuk mengalokasikan biaya pencegahan polusi dan tindakan kontrol untuk mendorong pengelolaan sumber daya lingkungan secara rasional dan menghindari penyimpangan pada perdagangan dan investasi internasional (Sands:281)

Rekomendasi tersebut berisi definisi prinsip pencemar yang mewajibkan para pencemar untuk memikul biaya-biaya yang diperlukan dalam rangka upaya-upaya yang diambil oleh pejabat publik untuk menjaga agar kondisi lingkungan berada pada kondisi yang dapat diterima atau dengan kata lain bahwa biaya yang diperlukan untuk menjalankan upaya-upaya ini harus mencerminkan harga barang dan jasa yang telah menyebabkan pencemaran selama dalam proses produksi atau proses konsumsinya (A. Boyle, 1994: 79-182)

Prinsip ini menetapkan persyaratan biaya akibat dari polusi dibebankan kepada pelaku yang bertanggung jawab menyebabkan polusi(Louka, :279.).Penerapan nyata dari prinsip pencemar membayar ini adalah pengalokasian kewajiban ekonomi terkait dengan kegiatan-kegiatan yang merusak lingkungan dan secara khusus berhubungan dengan tanggung-gugat (liability), penggunaan instrumen ekonomi, dan penerapan peraturan terkait persaingan dan subsidi (Sands:280)
Dengan melihat hal tersebut sebenanya Hukum internasional telah lama mengatur soal kewajiban bagi pelaku pencemaran lingkungan yang melewati batas suatu negara atau satu pihak ke pihak lainnya.Dikenal dengan istilah Transfrontier Pollution (TFP). Sejak awal dekade 1970-an permasalahan ini telah sering terjadi sehingga menimbulkan pemikiran tentang perlunya kesepakatan yang mengatur sekaligus mengatasi masalah tersebut. Contoh perjanjian yang telah disepakati yang mengatur masalah TFP ini adalah Perjanjian Brussel Berkenaan dengan intervensi di lautan Terbuka dalam hal Korban Pencemaran minyak (Brussels Convention Relating to Intervention on The High Seas InCases of Oil Pollution Casualties) serta Perjanjian Pertanggungan Sipil untuk Kerusakan Karena Pencemaran Minyak (Convention on Civil liability for Oil Pollution Damage).

Dua perjanjian itu dilatarbelakangi dengan terjadinya peristiwa kandasnya kapal tanker minyak Torrey Canyon, dilepas pantai Inggris pada tahun 1967. Kedua perjanjian di atas, disetujui pada tahun 1969 , menjadi pokok yang penting dalam pengaturan lingkungan hidup yang bersifat public goods atau barang umum seperti udara, air dan lautan.

Pada tahun 1972, OECD mengenalkan sebuah prinsip penting untuk menyelesaikan masalah pencemaran lingkungan hidup tersebut, yakni prinsip pencemar membayar (polluter pays principle). Prinsip ini pada awalnya hanya mengharuskan pada pihak pelaku pencemaran membayar semuabiaya untuk mengikuti aturan dan standar lingkungan hidup yang berlaku. Hal itu tentu saja menimbulkan sikap negatif, karena banyak negara atau kalangan swasta yang dengan seenaknya melakukan perusakan atau pencemaran lingkungan dengan dalih bahwa mereka telah membayar biaya tertentu untuk mengikuti berbagai macam peraturan lingkungan. Dengan kata lain, jika mereka telah mengikuti sebuah standar tertentu lingkungan, maka jika terjadi kerusakan atau pencemaran akibat aktivitasnya, ia dibebaskan dari tanggung jawab untuk ganti rugi pada korban, misalnya.

Pemanasan global yang disinyalir bisa merubah iklim global secara ekstrim ternyata lebih mempunyai dampak buruk bagi negara-negara miskin di Sub-Sahara Afrika daripada negaranegara maju.Padahal negara-negara majulah yang 


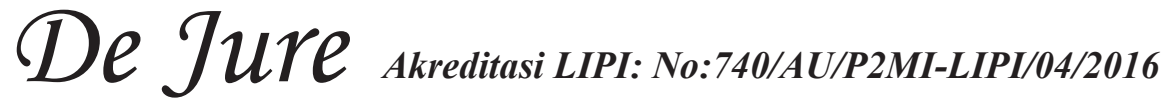

mempunyai kontribusi paling banyak terhadap fenomena pemanasan global daripada negaranegara lainnya, terutama dalam hal emisi gas rumah kaca yang dihasilkannya. Dengan kata lain, dengan terjadinya globalization of resources extraction, menyebabkan pihak yang menikmati keuntungan dari estraksi sumber daya itu serta pihak yang terkena imbas estraksi itu terpisah oleh batas geografi dan batas ekonomi serta keuntungan yang didapatkan oleh satu generasi, bisa jadi, menjadi kerugian pada generasi mendatang.

Hal itu menjadi alasan kenapa isu kerusakan lingkungan hidup ini harus menjadi tanggung jawab bersama, tanpa membedakan negara besar atau kecil, kaya atau miskin serta pelaku atau korban. Bukan berarti bahwa kewajiban hukum yang lahir kemudian karena perbedaan tindakan itu juga diandaikan sama. Pelaku pencemaran atau yang diindikasikan mempunyai kontribusi besar pada terjadinya kerusakan lingkungan global, tentu saja dan sudah menjadi keharusan, mempunyai kewajiban lebih besar daripada korban pencemaran atau yang tidak melakukan upaya-upaya perusakan lingkungan hidup.

Melihat fenomena itu, prinsip ini kemudian diperluas dengan mewajibkan kepada pelaku pencemaran untuk membayar biaya tertentu terhadap terjadinya kerusakan lingkungan yang disebabkan oleh aktivitasnya. Prinsip ini mewajibkan kepada pelaku untuk membayar dan bertanggung jawab terhadap setiap kerusakan lingkungan yang terjadi akibat aktivitasnya, tidak peduli apakah ia telah mengikuti standar lingkungan atau tidak. Prinsip pencemar membayar ini, dalam perkembangannya dan dalam dataran tertentu, mengatur masalah tanggung jawab sebuah negara ke negara lain atas kerusakan lingkungan hidup yang diperbuatnya. Prinsip ini lahir dari kewajiban negara untuk tidak merusak lingkungan negara lain atau teritorial di luar wilayahnya serta kewajiban tiap orang untuk menjaga kelestarian lingkungan hidup. Prinsip ini sekarang telah berlaku secara universal. Selain itu,dalam Konferensi Perserikatan Bangsa-Bangsa tentang Lingkungan dan Pembangunan atau yang lebih terkenal dengan sebutan Konferensi Tingkat Tinggi Bumi, yang terjadi pada tanggal 3-14 Juni 1992 di Rio de Janeiro, Brazil.

Beberapa pemerhati lingkungan sering menyerukan adanya zero pollution untuk kondisi dunia saat ini. Namun, ahli ekonomi dan bisnis memberi respon tidak percaya akan hal tersebut. Manakah yang lebih benar? Perlu adanya asumsi pencemaran itu didefiniskan secara tepat, negara harus mengurangi kadar pencemar sebanyakbanyaknya yang dirasakan memungkinkan. Akan tetapi, jika tidak didefinisikan dengan baik pollution control dapat menjadi dalih bagi Negara untuk memperlakukan suatu peraturan pada proses industry dan transaksi ekonomi. Pada akhirnya pollution control dalam pelaksanaanya lebih dikenal sebagai polluters pay principle (PPP).

Ada tiga pokok pikiran yang terkandung dalam prinsip pencemar membayar (polluter must pay principle/PPP) bahwa pertama, penegasan pada tanggung jawab bersama dan sama tiaptiap negara untuk melindungi lingkungan hidup baik pada pada tingkat nasional, regional maupun global; tanpa melihat negara besar atau kecil. Kedua, perhatian untuk melakukan usaha mencegah, mengurangi dan mengontrol ancaman terhadap lingkungan hidup didasarkan pada perbedaan keadaan masing-masing negara, khususnya dalam hal kontribusi tiap-tiap negara tersebut pada terjadinya pertambahan intensitas ancaman terhadap lingkungan hidup dan atau kerusakan lingkungan hidup yang terjadi, dan yang ketiga bahwa prinsip kebijakan lingkungan yang mengharuskan biaya pencemaran harus ditanggung oleh mereka yang menyebabkan itu.

\section{Strict Liability}

Selain prinsip pencemar membayar, sebelumyan juga dikenal dengan prinsip stric liability. Secara konsep, tanggung jawab mutlak (strict liability) awalnya dikenal pada kasus Rylands v Fletcher yang kemudian diadopsi dalam peraturan perundang-undangan nasional dan konvensi intenasional (Santosa:1998:hlm. 18)

Keputusan Court of Exchequer Chamber dalam kasus ini adalah kegiatan atau (1) aktivitas yang mengandung bahaya atau resiko, apabila mengakibatkan kerugian bagi orang lain (2) tidak memerlukan pembuktian apakah seseorang yang mengakibatkan kerugian tersebut memenuhi unsur kesalahan atau tidak. Penanggungjawab kegiatan yang berbahaya dan berisiko tersebut hanya dapat dibebaskan dari pertanggung jawaban apabila pelaku (3) dapat membuktikan bahwa kerugian yang timbul adalah akibat dari kesalahan penggugat sendiri atau akibat bencana alam (Sugianto, 2013) 
Dalam penerapannya di Indonesia, tanggung jawab mutlak dikenal dalam kasus-kasus lingkungan hidup dan diatur dalam regulasi bidang lingkungan hidup sejak Undang-Undang Nomor 23 Tahun 1997 tentang Pengelolaan Lingkungan Hidup, namun terdapat perbedaan yang cukup signifikan dengan Undang-Undang Nomor 32 Tahun 2009 tentang Perlindungan dan Pengelolaan Lingkungan Hidup. Perbedaan tersebut dapat dilihat pada Pasal 35 sebagaimana disebutkan:Ayat (1)Penanggung jawab usaha dan/atau kegiatan yang usaha dan kegiatannya menimbulkan dampak besar dan penting terhadap lingkungan hidup, yang menggunakan bahan berbahaya dan beracun, dan/atau menghasilkan limbah bahan berbahaya dan beracun, bertanggung jawab secara mutlak atas kerugian yang ditimbulkan, dengan kewajiban membayar ganti rugi secara langsung dan seketika pada saat terjadinya pencemaran dan/atau perusakan lingkungan hidup."Ayat (2) Penanggung jawab usaha dan/atau kegiatan dapat dibebaskan dari kewajiban membayar ganti rugi sebagaimana dimaksud pada ayat (1) jika yang bersangkutan dapat membuktikan bahwa pencemaran dan/atau perusakan lingkungan hidup disebabkan salah satu alasan di bawah ini: a. adanya bencana alam atau peperangan; atau b. adanya keadaan terpaksa di luar kemampuan manusia; atau c. adanya tindakan pihak ketiga yang menyebabkan terjadinya pencemaran dan/ atau perusakan lingkungan hidup. Ayat (3) Dalam hal terjadi kerugian yang disebabkan oleh pihak ketiga sebagaimana dimaksud pada ayat (2) huruf c, pihak ketiga bertanggung jawab membayar ganti rugi.
Pada Undang-Undang Nomor 23 Tahun 1997 tentang Pengelolaan Lingkungan Hidup,ganti rugi yang dibebankan harus diberikan secara langsung dan seketika ketika terjadi pencemaran dan/atau perusakan lingkungan.Terminologi ini dianggap menimbulkan perdebatan, karena tidak ada mekanisme yang mewajibkan pencemar dan/atau perusak lingkungan membayar ganti kerugian seketika dan langsung pada saat terjadi pencemaran dan/atau perusakan.Oleh karena itu pada perumusan Undang-Undang Nomor 32 Tahun 2009tentang Perlindungan dan Pengelolaan Lingkungan Hidup, makna tanggung jawab mutlak dikembalikan menjadi tanggung jawab tanpa pembuktian unsur kesalahan (BPHN:2015)

Pada Undang-Undang Nomor 23 Tahun 1997 tentang Pengelolaan Lingkungan Hidup, tanggung jawab mutlak masih memiliki pengecualian (batasan tanggung jawab pelaku usaha) jika penanggungjawab usaha dapat membuktikan apa yang disyaratkan pada ketentuan Pasal 35 ayat (2). Hal ini tentunya berbeda dengan ketentuan Pasal 88 Undang-Undang Nomor 32 Tahun 2009 tentang Perlindungan dan Pengelolaan Lingkungan Hidup,dimana pengecualian tidak diatur.

Tanggung jawab mutlak merupakan lex specialis dari gugatan PMH (liability based on fault), dimana unsur kesalahan dalam PMH tidak perlu dibuktikan oleh penggugat. Tabel di bawah ini akan menjelaskan perbedaan beban pembuktian antara $\mathrm{PMH}$ dan tanggung jawab mutlak (Sugianto, 2013)

Tabel

Perbedaaan Beban Pembuktian

\begin{tabular}{|c|c|}
\hline Perbuatan Melawan Hukum/Liability Based on Fault & Strict Liability/ Liability without Fault \\
\hline $\begin{array}{ll}\text { - } & \text { Kesalahan (fault) } \\
\text { - } & \text { Kerugian (damages) } \\
\text { - } & \text { Kausalitas (causal link) } \\
\text { - } & \text { Beban pembuktian terhadap ketiga unsur di atas terdapat } \\
& \text { pada penggugat (163 HIR dan } 1365 \mathrm{BW})\end{array}$ & $\begin{array}{l}\text { - } \quad \text { Kerugian (damages) } \\
\text { - } \quad \text { Kausalitas (causal link) } \\
\text { Beban pembuktian terhadap kedua } \\
\text { unsur di atas tetap merupakan beban } \\
\text { penggugat (163 HIR dan } 1365 \mathrm{BW}) \\
\text { Beban pembuktian tentang faktor } \\
\text { penghapus pertanggung jawaban/ } \\
\text { pembelaan ada pada diri tergugat } \\
\text { sebagaimana layaknya suatu } \\
\text { pembelaan (tidak terdapat pemindahan } \\
\text { beban pembuktian) }\end{array}$ \\
\hline
\end{tabular}




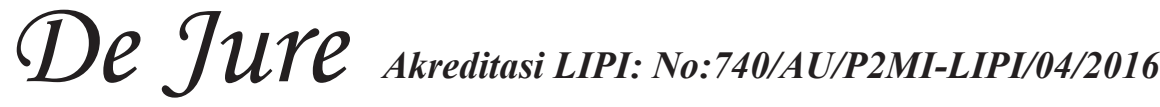

Berdasarkan tabel di atas dapat disimpulkan bahwa perbedaan mendasar dari PMH dan strict liability ada pada beban pembuktian unsur kesalahan.Jika pada PMH beban pembuktian unsur kesalahannya ada pada penggugat, maka pada strict liability beban pembuktian unsur kesalahannya ada pada tergugat, namun penggugat masih harus membuktikan unsur kerugian dan kausalitas. Selain itu, meskipun dalam Undang-Undang Nomor 32 Tahun 2009 tentang Perlindungan dan Pengelolaan Lingkungan Hidup,tidak mengatur secara tegas pengecualian bagi penerapan tanggungjawab mutlak, namun pelaku tetap dimungkinkan membuktikan faktor penghapus bagi pertanggungjawaban mutlak jika dianggap ada, yaitu kesalahan terdapat pada penggugat sendiri atau karena bencana alam. Hal ini tidak diatur mengingat penafsirannya sudah lazim dilakukan oleh hakim.

Isu lain mengenai ketentuan tanggung jawab mutlak dalam Undang-Undang Nomor 32 Tahun 2009 tentang Perlindungan dan Pengelolaan Lingkungan Hidup,terlihat dalam terminologi "sampai batas tertentu" dan "sampai batas waktu tertentu" pada penjelasan Pasal 88 sebagaimana terlihat :Yang dimaksud dengan "bertanggung jawab mutlak" atau strict liability adalah unsur kesalahan tidak perlu dibuktikan oleh pihak penggugat sebagai dasar pembayaran ganti rugi. Ketentuan ayat ini merupakan lex specialis dalam gugatan tentang perbuatan melanggar hukum pada umumnya. Besarnya nilai ganti rugi yang dapat dibebankan terhadap pencemar atau perusak lingkungan hidup, menurut Pasal ini dapat ditetapkan sampai batas tertentu. Yang dimaksud dengan "sampai batas waktu tertentu" adalah jika menurut penetapan peraturan perundang-undangan ditentukan keharusan asuransi bagi usaha dan/atau kegiatan yang bersangkutan atau telah tersedia dana lingkungan hidup".Kedua terminologi ini memiliki pengertian yang berbeda. Terminologi "sampai batas tertentu" menunjukan adanya batas ganti kerugian yang dibebankan terhadap pencemar atau perusak, sedangkan terminologi "sampai batas waktu tertentu" menunjukan kepada limitasi waktu. Terminologi "sampai batas waktu tertentu" dalam penjelasan Pasal 88 tidak relevan dengan penjelasan kalimat sebelumnya. Dalam akademis maupun risalah sidang, tidak ditemukan pembahasan mengenai "sampai batas waktu tertentu".
Kedua di atas dilekatkan dengan ketentuan asuransi. Oleh karena itu, penafsiran tentang terminologi ini lebih tepat jika dikaitkan dengan limitasi pertanggungan yang akan dibayarkan oleh perusahaan asuransi atas resiko pencemaran atau perusakan lingkungan yang terjadi. Yang perlu diingat bahwa dalam skema asuransi ini, bisa jadi kerugian yang muncul akibat pencemaran atau perusakan lingkungan hidup ternyata melebihi batas pertanggungan tersebut. Klausul "dapat" pada penjelasan yang menyatakan" nilai ganti rugi yang dapat dibebankan terhadap pencemar atau perusak lingkungan hidup menurut Pasal ini dapat ditetapkan sampai batas tertentu" mengindikasikan bahwa hakim tetap harus mempertimbangkan apakah batas pertanggungan tersebut mencukupi untuk membayar kerugian yang ditimbulkan atau tidak. Jika tidak, maka selisih pembayaran kerugian harus dibebankan kepada pelaku, mengingat prinsip asal dari pertanggungjawaban bahwa pelaku harus mempertanggungjawabkan kerugian yang timbulkan oleh perbuatannya. Ketentuan asuransi lingkungan memudahkan pembayaran seketika (atau dengan proses yang cepat) bagi pelaku agar tidak memberikan pengaruh yang signifikan terhadap posisi keuangannya. Sedangkan bagi korban, akan lebih cepat mendapatkan pembayaran untuk kebutuhan pemulihan atas kerugian yang dideritanya. Oleh karena itu, ketentuan ini memiliki urgensi yang tinggi untuk diatur dalam peraturan tentang asuransi lingkungan.

\section{Dasar Hukum Nasional terhadap Pencemaran di Laut}

Beberapa aturan hukum nasional mengenai pencemaran di laut antara lain:

- $\quad$ Undang-Undang Nomor 32 Tahun 2014 tentang Kelautan, diatur dalam Pasal 52

- $\quad$ Undang-Undang Nomor 32 Tahun 2009 tentang Perlindungan dan Pengelolaan Lingkungan Hidup.

- Peraturan Pemerintah Nomor 19 Tahun 1999 tentang Pengendalian Pencemaran dan/atau Perusakan Laut.

- Peraturan Presiden Nomor 109 Tahun 2006 tentang Penanggulangan Keadaan Darurat Tumpahan Minyak di Laut. 
2. Dasar Hukum Lingkungan Internasional terhadap Pencemaran di Laut

a. Convention on the Prevention of Marine Pollution by Dumping of Wastes and Other Matter (London Dumping) 1972.

b. International Convention for the Prevention of Pollution from Ships 1973/1978 (MARPOL 1973/1978).

Marpol memuat 6 (enam) Annexes yang berisi regulasi-regulasi mengenai pencegahan polusi dari kapal terhadap:

- Annex I - Oil (Minyak)

- Annex II - Nixious Liquid Substance Carried in Bulk (cairan Nox berbentuk curah)

- Annex III - Harmful Substance in Packages Form (barang-barang berbahaya dalam kemasan)

- $\quad$ Annex IV - Sewage (air kotor/air pembuangan)

- $\quad$ Annex V - Garbage (sampah)

- Annex VI - Air Pollution (polusi udara)

\section{B. Pendekatan yang digunakan oleh Indonesia dalam implementasi prinsip pencemar membayar.}

Salah satu dampak negatif aktivitas manusia di laut adalah terjadinya pencemaran.Pencemaran laut sendiri dapat diakibatkan oleh tumpahan minyak karena kecelakaan kapal, limbah yang dibuang oleh pabrik ke laut, dan bocornya tambang minyak lepas pantai, atau dumping yang sengaja dilakukan oleh kapal.Dalam dunia internasional, pencemaran laut seringkali mengakibatkan perselisihan diantara negara - negara yang dibatasi dengan laut atau selat. Contoh kasus adalah pencemaran laut, akibat kecelakaan kapal Exxon Valdez di Laut Alaska pada tahun 1989 yang menumpahkan 37.000 ton minyak mentah. Kasus tenggelamnya kapal Prestige di Selat Spanyol tahun 2002 (menumpahkan 77.000 ton minyak) yang mengakibatkan kerugian yang besar dan mencemari laut dua negara (Prancis dan Spanyol) sehingga merugikan industri perikanan negara tersebut.

Di perairan Indonesia juga sudah bukan hal yang baru jika pencemaran lautnya banyak terjadi, baik yang diakibatkan oleh kecelakaan kapal maupun aktivitas pertambangan laut.Seringkali melalui pemberitaan beberapa media diketahui banyak terjadi pengotoran wilayah pantai, perusakan terumbu karang, matinya ribuan ikan, sampai pada berita mengenai tragedi tumpahan minyak dari kilang Montara.Hal ini sudah seharusnya dapat diantisipasi sejak awal.

Pemerintah mestinya mampu membentengi seluruh sumber daya alam dan keindahan biota laut dengan perangkat aturan-aturan hukum dari potensi pencemaran laut demi kelangsungan ekosistem laut itu dalam jangka panjang.Masalah kerusakan lingkungan laut di dalam wilayah perairan Indonesia tampaknya menjadi sesuatu yang biasa saja terjadi, dan pemerintah seolaholah lalai dalam menjalankan tugas dan fungsinya menjaga dan melindungi wilayah laut.

Saat ini industri minyak dunia telah berkembang pesat, sehingga kecelakaankecelakaan yang mengakibatkan tercecernya minyak di laut hampir tidak bisa dielakkan. Kapal tanker mengangkut minyak mentah dalam jumlah besar setiap tahun. Jika terjadi pencemaran laut akan mengakibatkan minyak mengapung di atas permukaan laut yang akhirnya terbawa arus dan terbawa ke pantai. Data pada tabel diatas menunjukkan betapa tumpahan minyak (oil spill) dalam jumlah yang besar mengakibatkan rusaknya lingkungan dan mempengaruhi pola kehidupan di laut baik yang dilakukan oleh para nelayan maupun mahluk hidup lainnya yang menggantungkan hidupnya di laut.

Demikian halnya untuk kasus-kasus lain seperti pencucian tangki, air ballast yang berfungsi sebagai penyeimbang hidrostatik bagi tangker saat tidak memuat minyak. Air ballast bersal dari alir laut yang dipompakan kedalam storage tanks yang terletak pada bagian lambung dibawah geladak. Dalam keadaan tertentu kapal tanker boleh melakukan pembuangan ballast, namun tetap berpedoman pada panduan sistem dan prosedur load on top sebelum tiba di terminal.

Salah satu isi panduan adalah residu/oil, sludge hasil pembersihan tangki harus tetap berada dalam kapal dan boleh dibuang di pelabuhan muat yang memiliki fasilitas penampung buangan ballas kotor. Kenyataan di lapangan membuktikan bahwa pencemaran laut karena buangan ballast kotor yang tercampur dengan residu/oil sludge sering dijumpai di perairan Indonesia. Hal ini dapat terjadi karena pihak pelabuhan tidak menyediakan 


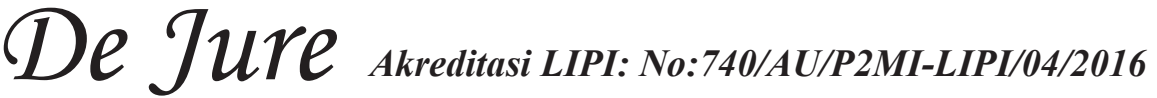

fasiltas dengan daya tampung yang mencukupi sehingga operator kapal cenderung melakukan pembuangan ballas kotor yang disengaja ke laut kawasan antar pulau maupun di wilayah Zona Economi Eckslusif.Oleh karena itu, peran fasilitas penampungan (reception facilities) menjadi amat penting untuk mengurangi frekuensi pembuangan limbah.

Pencemaran lingkungan laut diartikan dengan membuang sampah dari kapal di laut lepas, atau membuang limbah minyak serta barang cair lainnya yang ditampung dalam tangkitangki penampungan di dasar palkah atau kamar mesin dibawah permukaan laut, atau laut tercemar oleh minyak karena kapal karam atau tenggelam. Pencemaran tentunya tidak terlepas dari banyaknya konsumsi energi karena perkembangan pesat teknologi saat ini.Meskipun produksi minyak terus menurun. Akan tetapi dengan konsumsi yang terus meningkat akibatnya aktivitas pengangkutan (transportasi) juga meningkat. Dengan demikian, potensi pencemaran, akan terus mengancam manakala tidak dibarengi dengan pengawasan dan pemanfaatan sarana transportasi (kapal tanker) yang berwawasan lingkungan, seperti double hull tanker.

\section{Kasus Nasional}

Beberapa contoh kasus pencemaran pada umumnya yang telah dan sedang mendapat perhatian serius bangsa Indonesia saat ini adalah Kasus lumpur Lapindo, Kasus Teluk Buyat Sulawesi Utara kasus limbah di perairan laut. Kasus lumpur Lapindo berupa semburan lumpur panas, muncul pertama kalinya pada 29 Mei 2006 sekitar pukul 05.00.WIB. Terjadi di areal persawahan Desa Siring, Kecamatan Porong. Kabupaten Sidoarjo sekitar 150 meter barat daya sumur Banjar Panji 1 yang dikerjakan oleh Lapindo Brantas Inc. Selama tiga bulan Lapindo Brantas Inc, melakukan pengeboran vertikal untuk mencapai formasi geologi yang disebut Kujung pada kedalaman 10.300 kaki. Sampai semburan lumpur pertama itu, yang dalam dunia perminyakan dan gas disebut blow out, telah mencapai kedalaman 9.297 kaki (sekitar 3,5 kilometer). Kedalaman ini dicapai pukul 13.00 WIB dua hari sebelum blow out.

Kelaziman pada pengeboran di kedalaman tersebut, lumpur berat masuk pada lapisan disebut loss, yang memungkinkan terjadinya tekanan tinggi dari dalam sumur ke atas atau kick, antisipasinya menarik pipa untuk memasukkan casing yang merupakan pengaman sumur. Ketika penarikan pipa hingga 4.241 kaki, pada 28 Mei 2006 terjadi kick. Penanggulangan ini adalah dengan penyuntikan lumpur ke dalam sumur. Ternyata bor macet pada $3.580 \mathrm{kaki}$, dan upaya pengamanan lain dengan disuntikan semen. Bahkan pada hari itu dilakukan fish, yakni pemutusan mata bor dari pipa dengan diledakan. Kemudian yang terjadi adalah semburan gas dan lumpur pada subuh esok harinya (http://jurnalsrigunting.com/tag/kasuslumpur-lapindo, Diakses 10 Mei 2016 jam 10.30 WIB)

Kasus pencemaran perairan Teluk Buyat Sulawesi Utara, penyebabnya adalah pencemaran air laut akibat logam berat arsen (As) dan merkurium $(\mathrm{Hg})$ yang telah melebihi ambang batas yang ditetapkan. Terkait ini, PT Newmont Minahasa merupakan perusahaan yang dituding sebagai biang keladi pencemaran ini, karena membuang sailing (batuan dan tanah sia ekstraksi bijih emas) ke dasar laut di Teluk Buyat. Oleh itu, tragedi Minamata yang pernah terjadi di Jepang pada 1960-an, dapat terjadi di Indonesia kini (http://perpustakaan.bappenas.go.id/lontar/ filedigital/blob/F15002/Bersikap/Arif/atas/ Kasus/Teluk/Buyat-l.htm, di akses 10 Mei 2016 jam 9.30 WIB)

Saat itu terjadi pencemaran merkurium dalam kadar yang tinggi di Teluk Minamata, Jepang. Dampaknya, masyarakat sekitar yang mengkonsumsi ikan menderita penyakit gangguan saraf dan kanker yang terjadi setelah sekian belas tahun perusahaan batu baterai dan aki yang ada di sana beroperasi. Lepas dari tudingan minor, yang jelas industri pertambangan memang menjadi salah satu faktor utama di balik maraknya pencemaran lingkungan hidup. Bahkan, industri ini juga turut andil dalam perusakan kawasan hutan lindung. Konfirmasi, menurut siaran pers Walhi pada 10 April 2002 bahwa kawasan hutan lindung atau konservasi yang saat ini benar-benar sudah terancam keberadaannya diantaranya: hutan lindung Pulau Gag-Papua yang sudah resmi menjadi lokasi proyek PT. Gag Nickel/ BHP, Tahura Poboya-Paneki oleh PT Citra Palu Mineral/Rio Tinto, Palu (Sulawesi Tenggara) dan juga Taman Nasional Meru Betiri di Jember, Jatim, oleh PT Jember Metal Banyuwangi Mineral dan PT. Hakman(http://perpustakaan.bappenas. 
go.id/lontar/filedigital/blob/F15002/Bersikap/ Arif/atas/Kasus/Teluk/Buyat-l.htm, di akses 10 Mei 2016 jam 9.30 WIB)

Ribuan ton limbah diantaranyaterkontaminasi bahan beracun dan berbahaya dapat mencemari daratan dan perairan Indonesia. Sebagian limbah diimpor dari sejumlah negara, yang berisiko bagi lingkungan hidup dan kesehatan. Di perairan utara Jakarta, misalnya gumpalan minyak secara berkala mengapung di laut terbawa angin ke pulau-pulau di Kepulauan Seribu. Tak hanya mengganggu pemandangan, limbah cucian lambung kapal tanker itu juga merusak lingkungan hidup dan mengancam biota laut (http://www.kemenperin.go.id/artikel/3185/Ribuan-Ton-LimbahBerisiko, Diakses :10 Mei 2016 Jam 14.30 WIB)

Hal yang sama ditemui di perairan sekitar Pulau Batam, Kepulauan Riau. Batam tergolong rentan dimasuki limbah karena posisinya yang terbuka dan berbatasan langsung dengan negara lain. Salah satu kasus yang hingga kini belum tuntas adalah timbunan 3.800 ton ampas tembaga di sebelah Kantor Camat Sagulung, Batam, yang diimpor dari Korea Selatan tahun 2009. Dua warga negara Korsel dan satu warga negara Indonesia menjadi tersangka.Hingga kini, pihak perusahaan bersikukuh limbah itu adalah pasir besi, bahan pembersih karat kapal (Saputro: 2004.)

\section{Kasus Internasional}

Selain pemaparan kasus-kasus tersebut, kasus lingkungan hidup yang dapat dicermati dalam perspektif international antara lain kasus Agent Orange, kasus Strom King, kasus Tarrey Canyon, kasus Trail Smelter. Kasus Agent Orange (1987) merupakan kasus yang diajukan oleh ribuan veteran perang Vietnam terhadap penghasil pabrik kimia beracun yang mempergunakan bahan tersebut sebagai defolian dalam perang Vietnam. Kasus ini dinamakan dengan kasus Agent Orange yaitu salah satu jenis dioksin sebagai penyebab timbulnya kerugian dan penderitaan fisik maupun emosional (Santosa, 1997:84))

Kasus Strom King di New York Amerika, suatu perusahaan swasta yang bergerak di bidang penyediaan tenaga listrik, yaitu:consolidate edison di New York telah mencoba sejak tahun 1962 untuk membangun industri pusat listrik tenaga air di Strom King di Houdson Higlands. Rencana tersebut telah mengundang reaksi dari berbagai pihak.Mula-mula dengan alasan merusak keindahan alam, tetapi kemudian ditambah dengan alasan bahwa instalasi tersebut secara potensial dapat mencemarkan air di sekitarnya dan ikan dapat musnah (Hardjasoemantri, 2006:404.)

Kasus tentang kandasnya kapal tangki Tarrey Canyon tahun 1967 di Selat Inggris yang menimbulkan tumpahan minyak dalam jumlah besar telah mengakibatkan pencemaran dan kerusakan pantai Inggris secara parah dan kegiatan tersebut tergolong kegiatan dengan resiko tinggi dan berbahaya (Hardjasoemantri, 2006:417). Selanjutnya dalam kasus Trail Smelter (1938), As. Vs Kanada kasus trail smelter (trail smelter case) bermula dari kasus pencemaran udara yang diakibatkan oleh sebuah perusahaan pupuk milik warga negara Kanada yang dioperasikan di wilayah Kanada dekat sungai Columbia, lebih kurang 10 mil menjelang perbatasan Kanada dan Amerika Serikat. Mulai tahun 1920 produksi emisi perusahaan tersebut terus meningkat. Emisi tersebut mengandung sulfur dioksida menyebarkan bau logam dan seng yang sangat menyengat. Pada tahun 1930 jumlah emisi tersebut mencapai lebih dari 300 ton sulfur setiap hari. Emisi tersebut karena dibawa angin bergerak ke wilayah AS melalui limbah sungai Columbia dan menimbulkan berbagai akibat merugikanterhadap sawah, air dan udara, kesehatan serta berbagai kepentingan penduduk Washington lainnya (Putra, 2003:45.)

\section{Hambatan dalam penerapannya dan bagaimana upaya pemerintah dalam mengatasinya.}

Hambatan utama penerapan PPP dalam UU Kelautan adalah ketidakjelasan pengaturan mengenai PPP. Dalam UU Kelautan, PPP tidak diaturdalamketentuanmengenai “asas", melainkan langsung ditempatkan dalam ketentuan mengenai sengketa dan penerapan sanksi. Penempatan PPP dalam ketentuan mengenai sengketa dan penerapan sanksi tentunya membatasi potensi penerapan PPP. Selain itu, pengaturan PPP dalam UU Kelautan juga tidak diatur dengan detail. UU Kelautan hanya mengamanatkan bahwa ketentuan lebih lanjut mengenai PPP dilaksanakan sesuai dengan ketentuan peraturan perundang-undangan.

Ketidakjelasan pengaturan mengenai PPP juga mengakibatkan timbulnya masalah mengenai pihak mana saja yang memiliki kewenangan 


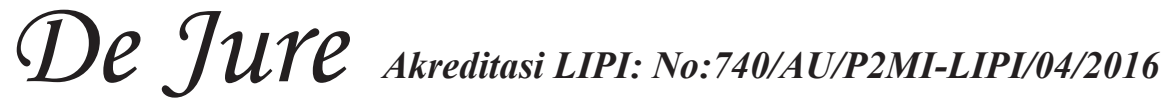

dalam penegakan hukum. Walaupun Bakamla memiliki kewenangan untuk melakukan sinergi dan koordinasi, KKP dan KLHK juga memiliki kewenangan untuk langsung melakukan penegakan hukum. Ketidakjelasan pengaturan dalam UU Kelautan dapat diatasi dengan memperkuat koordinasi dengan kementerian terkait. Perihal mengenai peluang penerapan PPP berdasarkan kelembagaan yang ada akan dijelaskan lebih lanjut pada bagian ketiga.

Upaya pemerintah untuk mengatasinya penerapan prinsip pencemar membayar ini adalah dimana dalam hal pencemaran laut dan bencana kelautannya, maka Pemerintah menetapkan kebijakan penanggulangan dampaknya, yaitu dengan:

a) pengembangan sistem mitigasi bencana;

b) pengembangan sistem peringatan dini (early warning system);

c) pengembangan perencanaan nasional tanggap darurat tumpahan minyak di Laut;

d) pengembangan sistem pengendalian pencemaran Laut dan kerusakan ekosistem Laut; dan

e) pengendalian dampak sisa-sisa bangunan di Laut dan aktivitas di Laut.

Pemerintah dan menyelenggarakan Pemerintah Daerah wajib menerapkan sistem pencegahan dan penanggulangan pencemaran dan kerusakan lingkungan Laut. Pemerintah dan Pemerintah Daerah wajib menyelenggarakan sistem pencegahan dan penanggulangan bencana Kelautan sebagai bagian yang terintegrasi dengan sistem pencegahan dan penanggulangan bencana nasional. Pemerintah bertanggungjawab dalam melindungi dan melestarikan lingkungan Laut. Pelindungan dan pelestarian lingkungan Laut dilakukan melalui pencegahan, pengurangan, dan pengendalian lingkungan Laut dari setiap Pencemaran Laut serta penanganan kerusakan lingkungan Laut. Pemerintah bekerjasama, baik bilateral, regional, maupun multilateral dalam melaksanakan pencegahan, pengurangan, dan pengendalian pencemaran lingkungan laut melalui prinsip pencemar membayar tersebut.

\section{KESIMPULAN}

Penerapan prinsip pencemar membayar (polluters pays principles) dalam Undang-Undang
No. 32 Tahun 2014 tentang Kelautan, tidak secara khusus diatur. Undang-undang tersebut pada pasal 52 ayat (3) menyebutkan Prose penyelesaian sengketa dan penerapan sanksi Pencemaran Laut sebagaimana dimaksud pada ayat (1) dan ayat (2) dilaksanakan berdasarkan prinsip pencemar membayar dan prinsip kehati-hatian. Hal tersebut tidak mengakibatkan prinsip tersebut tidak dapat diterapkan bila terjadi pencemaran dan/atau perusakan di laut. Dasarnya adalah ayat (4) dari Pasal 52 tersebut, yang menyebutkan ketentuan lebih lanjut mengenai proses penyelesaian dan sanksi terhadap pencemaran laut dilaksanakan sesuai dengan ketentuan perundang-undangan. Perundang-undangan yang dapat menerapkan prinsip pencemar membayar adalah UndangUndang Nomor 32 tahun 2009 tentang Perlindungan dan Pengelolaan Lingkungan Hidup, khususnya pada pasal 87 dan 88, yaitu yang mengatur mengenai pertanggungjawaban perdata.

\section{SARAN}

Proses penerapan prinsip pencemar membayar di laut perlu dikonkritkan dengan adanya sinergi antar kelembagaan. Alasannya adalah, banyak kelembagaan terkait dan memiliki dasar hukum yang berbeda, yang dapat berakibat tidak optimal dalam pelaksanaannya. 


\section{DAFTAR KEPUSTAKAAN}

A. Boyle, Impact of International Law and Policy, dalam: Alan Boyle, ed., Environmental Regulation and Economic Growth (Clarendon Press, 1994), hlm. 179-182. Lihatjuga: Alan Boyle dan Patricia Birnie, International Law and the Environment, Second Edition, (Oxford University Press, 2002).

BAPPENAS, Konsep Meinstreamin Ocean Policy Kedalam Rencama Pembangunan Nasional; Kedeputian Bidang Sumber daya Alam dan Lingkungan, 2014.

BPHN, Laporan Akhir Tim Pengkajian Hukum Tentang Impementasi Peinsip Pencemar Membayar Menurut Undang-Undang Nomor 32 Tahun 2014 tentang Kelautan (Ketua: Dr. Harsanto Nursadi, SH.,MSi),Jakarta 2015.

Elli Louka, International Environmental Law, Fairness, Effectiveness, and World Order, (United Kingdom: Cambridge University Press, 2006).

Philippe Sands, Principles of International Environmental Law.

Indro Sugianto, S.H., M.H,Penegakan Hukum Lingkungan Aspek Keperdataan, Dipresentasikan Pelatihan Sertifikasi Hakim Lingkungan Jumat, 15 November 2013.

Depri, 2014, Pertanggungjawaban Korporasi dalam Kasus Lumpur Lapindo, Available at: http://jurnalsrigunting.com/tag/kasuslumpur-lapindo, Diakses 10 Mei 2016 jam 10.30 WIB.

Masnellyarti Hilman, 2014, Ribuan Ton Limbah Berisiko, Available at:http://www.kemenperin.go.id/artikel/3 185/Ribuan-TonLimbah-Berisiko, Diakses :10 Mei 2016 Jam 14.30 WIB.

Koesnadi Hardjasoemantri, 2006, Hukum Tata Lingkungan, Edisi VIII, Cet.XIX, Gajah Mada University Press, Jogyakarta.

Ida Bagus Wyasa Putra, 2003, Hukum Lingkungan Internasional,PerspektifBisnisInternasional, Refika Aditama, Bandung, Cetatakan I.

Indonesia, UU No. 32 Tahun 2014 tentang Kelautan.
Indonesia, UU No. 32 Tahun 2009 tentang Perlindungan dan Pengelolaan Lingkungan Hidup.

Santosa, Mas Ahmad, 1997, Konsep dan Penerapan Gugatan Perwakilan (Class Action), ICEL, (selanjutnya disebut Mas Ahmad Santosa II).

Santosa, Mas Achmad, et.al, Penerapan Asas Tanggung Jawab Mutlak (strict liability) di bidang lingkungan hidup, (Jakarta : ICEL), 1998.

Saputro, Edy Purwo, 2004, Bersikap Arif atas Kasus Teluk Buyat, Available at: http:// perpustakaan.bappenas.go.id/lontar/ filedigital/blob/F15002/Bersikap/Arif/atas/ Kasus/Teluk/Buyat-l.htm, di akses 10 Mei 2016 jam 9.30 WIB.

Soerjono Soekamto dan Sri Mamuji 1990: Penelitian Hukum Normatif. Suatu Tinjauan Singkat, CV Rajawali, Jakarta. Lihat juga Soerjono Soekanto dan Sri Mamuji, Penelitian Hukum Normatif: Suatu Tinjauan Singkat, Edisi 1 Cet. V (Jakarta: PT Raja Grafindo Persada, 2001).

http://www.uruqulnadhif.com/2015/06/uukelautan-uu-pengelolaan-wilayah.html, diaksesharisenin, 28 November 2016, pukul 7.30 WIB. 


\section{De JuTe akreditasi LIPI: No:740/AU/P2MI-LIPI/04/2016}

\section{BIODATA PENULIS}

Nama, Muhar Junef, S.H., M.H., lahir di Sungai Penuh 16 Juni 2016. Pendidikan S1 pada Fakultas Hukum Universitas Bung Hatta Padang Lulus Tahun 1988; Pendidikan S2 pada Pasca Sarjana Fakultas Hukum Universitas Indonesia Jakarta Lulus Tahun 2004. Tahun 1991 s.d Tahun 2015 bekerja pada Badan Pembinaan Hukum Nasional Kementerian Hukum dan Hak Asasi Manusia RI; Tahun 2016 bekerja pada Badan Penelitian dan Pengembangan Hukum dan Hak Asasi Manusia Kementerian Hukum dan Hak Asasi Manusia RI. Alamat Kantor Jl. HR Rasuna Said Kav 4-5 Kuningan Jakarta Selatan 12940 Telp (021) 252505 ext.512 Fax (021) 2522954 Laman: www.balibangham.go.id; Alamat Rumah: Pondok Surya Mandala Balok F No. 5 Kelurahan Jakamulya Bekasi Selatan. Telp. (021) 82419060; HP. 081311649214. Email: muharjunef@yahoo.co.id. 


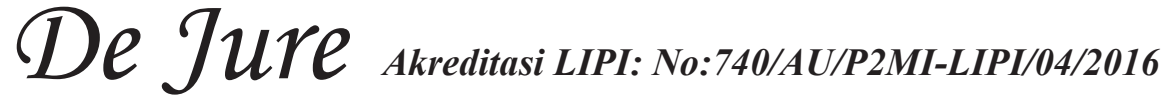

\section{PEDOMAN PENULISAN NASKAH JURNAL PENELITIAN HUKUM DE JURE}

1. Naskah yang dimuat dalam Jurnal Penelitian Hukum De Jure adalah tulisan yang belum pernah dipublikasikan dalam media massa.

2. Naskah yang dimuat dalam Jurnal Penelitian Hukum De Jure meliputi tulisan tentang hasil penelitian (penelitian empiris maupun penelitian normatif atau studi dokumenter), pemikiran dan informasi lain yang bersifat ilmiah.

3. Menggunakan bahasa Indonesia yang baku.

4. Sistimatika Penulisan :

A. Naskah artikel hasil penelitian empiris :

o Judul aktual

Menggambarkan isi naskah dan maksimal 14 kata ditulis dalam bahasa Indonesia dan Inggris

o Nama penulis

Tanpa gelar akademik, jabatan, kepangkatan, alamat lembaga/instansi dan e-mail

o Abstrak

Berisi Latar Belakang, Rumusan Masalah, Tujuan, Kegunaan, Metode, Isi

Pembahasan, Analisis, Kesimpulan dan Saran Temuan ditulis dalam satu spasi;

150 kata (10-20 baris/ satu (1) paragraf) diketik menggunakan huruf Times New

Roman; font 11 italic; ditulis dalam bahasa Indonesia dan bahasa Inggris.

o Kata Kunci

Mengandung yang di indekskan ditulis dalam bahasa Indonesia dan Inggris

dengan minimal 3 kata maksimal 5 kata

- PENDAHULUAN

Berisi latar belakang masalah dan rumusan masalah, tujuan, kegunaan, kerangka Teori/Konsep, Metode (metode penelitian yang digunakan, di antaranya meliputi jenis penelitian, lokasi penelitian, sumber data, teknik pengumpulan data, pengolahan data dan analisis data.)

- PEMBAHASAN

Berisi, pembahasan terhadap masalah yang diteliti

- Analisis

Berisi analisis dari semua pokok pembahasan

- PENUTUP

Kesimpulan dan saran

Kesimpulan dan saran ditulis dalam bentuk uraian bukan dalam bentuk'angka

- DAFTAR KEPUSTAKAAN

Daftar Pustaka : ditulis berdasarkan abjad, dengan urutan : Nama pengarang. Judul buku. Kota penerbit: nama penerbit, tahun penerbitan.

Contoh ....Hamzah. Andi, Bantuan Hukum suatu Tinjauan Yuridis. Ghalia

Indonesia, Jakarta, 1983. 


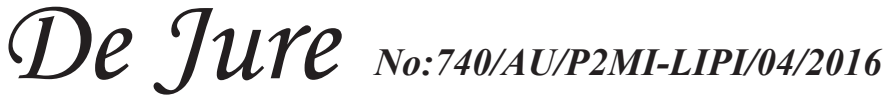

B. Naskah artikel ulasan Hasil penelitian normatif atau studi dokumenter), pemikiran dan informasi lain yang bersifat ilmiah.

o Judul aktual

Menggambarkan isi naskah dan maksimal 14 kata ditulis dalam bahasa

Indonesia dan Inggris

o Nama penulis

Tanpa gelar akademik, jabatan, kepangkatan, alamat lembaga/instansi dan e-mail

o Abstrak

Berisi Latar Belakang, Rumusan Masalah, Tujuan, Kegunaan, Metode, Isi

Pembahasan, Analisis, Kesimpulan dan Saran Temuan ditulis dalam satu spasi;

150 kata (10-30 baris/ satu (1) paragraf) diketik menggunakan huruf Times

New Roman; font 11 italic; ditulis dalam bahasa Indonesia dan bahasa Inggris

o Kata Kunci

Mengandung yang di indekskan ditulis dalam bahasa Indonesia dan Inggris

minimal 3 kata maksimal 5 kata

- PENDAHULUAN

Latar belakang masalah dan rumusan masalah

- PEMBAHASAN

Berisi, pembahasan terhadap masalah yang dikaji

- ANALISIS

Berisi analisis dari semua pokok pembahasan

- PENUTUP

Kesimpulan Dan Saran

Kesimpulan dan saran ditulis dalam bentuk uraian bukan dalam bentuk angka

- DAFTAR KEPUSTAKAAN

Daftar Pustaka : ditulis berdasarkan abjad, dengan urutan : Nama pengarang. Judul buku. Kota penerbit : nama penerbit, tahun penerbitan.

Contoh ....Hamzah. Andi, Bantuan Hukum suatu Tinjauan Yuridis. Ghalia

Indonesia, Jakarta, 1983.

5. Naskah dilengkapi dengan indeks.

6. Naskah diketik rapi 1,5 spasi di atas kertas A4; menggunakan huruf Times New Roman; Font 11; antara 20-30 halaman; diprint out dan disertai soft copy CD.

7. Penulisan kutipan sumber rujukan dengan sistem bodynote, yaitu menulisk ${ }^{\wedge} \mathrm{n}$ nama pengarang (tanpa gelar akademik); tahun penerbitan dan no halaman, yang ditulis dalam kurung; diletakan dibelakang kutipan. Contoh : .(Hamzah, 2007: 15)

8. Isi tulisan di luar tanggungjawab redaksi. Dan redaksi berhak mengedit redaksional tanpa merubah arti.

9. Naskah yang belum memenuhi syarat akan dikonfirmasikan atau dikembalikan untuk diperbaiki.

10. Keterangan lengkap dapat menghubungi redaksi Jurnal Peneltian Hukum De Jure melalui Email: jurnaldejure@yahoo.com 
